\title{
The Relative Importance of Natural Disturbances and Local Site Factors on Woody Vegetation Regeneration Diversity across a Large, Contiguous Forest Region
}

\author{
Gerardo P. Reyes ${ }^{1,2^{*}}$, Daniel Kneeshaw ${ }^{1}$, Louis de Grandpre ${ }^{1,3}$ \\ ${ }^{1}$ Department of Biological Sciences, Centre for Forest Research, University of Quebec in Montreal, Montreal, \\ Canada \\ ${ }^{2}$ Faculty of Interdisciplinary Studies, Lakehead University, Orillia, Canada \\ ${ }^{3}$ Natural Resources Canada, Canadian Forest Service, Laurentian Forestry Centre, Ste-Foy, Canada \\ Email: "gerardo1reyes@gmail.com, kneeshaw.daniel@uqam.ca, Louis.DeGrandpre@RNCan.gc.ca \\ Received February $3^{\text {rd }}, 2013$; revised April 21 $1^{\text {st }}, 2013$; accepted May $11^{\text {th }}, 2013$
}

Copyright (C) 2013 Gerardo P. Reyes et al. This is an open access article distributed under the Creative Commons Attribution License, which permits unrestricted use, distribution, and reproduction in any medium, provided the original work is properly cited.

\begin{abstract}
Stand-level diversity after natural disturbance can potentially differ across a large, contiguous forest region despite being dominated by the same canopy species throughout as differences in disturbance types and local site conditions can regulate species distribution. Our main objective was to examine the relative importance of natural disturbances (spruce budworm (Choristoneura fumiferana) outbreak, windthrow, and their interaction) and local site factors (climate, physiography, and stand structure and composition variables) on woody vegetation diversity among three, physiographically distinct locations across a large, contiguous forest region. Seventy-six Abies balsamea-Betula spp. stands affected by natural disturbance were compared and analysed using canonical ordination methods, diversity indices, and ANOVA. Different combinations of factors were important for vegetation re-establishment at each location. Differences in alpha $(\alpha)$, beta $(\beta)$, gamma $(\gamma)$, Shannon's $H^{\prime}$, and evenness $(J)$ diversity indices were observed among locations across the study region. Our findings indicate that while certain processes are important for maintaining canopy dominance by Abies balsamea and Betula spp. throughout the region, different combinations of factors were important for creating variation in woody species diversity among locations that resulted in greater woody species diversity at the regional scale.
\end{abstract}

Keywords: Regeneration; Natural Disturbance; Environmental Factors; Species Diversity; Eastern Boreal Mixedwood Region

\section{Introduction}

Climate determines the regional species pool (Dansereau, 1954; Neilson et al., 1992; Messaoud et al., 2007). However, woody species distribution and abundance across the landscape is largely determined by the disturbance regime (Gromtsev, 2002; Belote et al., 2009). Consequently, a distinct spatio-temporal arrangement of woody species is often observed at local scales due to variation in disturbance type, severity, and frequency across the landscape (Chen \& Popadiouk, 2002; Reyes et al., 2010). Apart from natural disturbances, local site factors also play key roles in forest development, as they are capable of influencing the disturbance regime itself, and can directly affect species diversity after disturbance (Peterson, 2000; McGuire et al., 2002; Wang et al., 2006).

Different types of disturbance influence regeneration patterns in distinctive ways depending on the severity of effects on forest vegetation and stand structure, and the variation in the temporal release of newly available resources. Windthrow and spruce budworm (Choristoneura fumiferana) outbreak, for example, have been shown to result in alternative successional

\footnotetext{
${ }^{*}$ Corresponding author.
}

trajectories in boreal ecosystems due to differences in the degree of soil disturbance and in the timing of tree mortality (Krasny \& Whitmore, 1992; Nagel \& Diaci, 2006). In the case of windthrow, this disturbance type can substantially alter canopy species dominance whereas budworm damage can simply delay or promote development towards late-succession conditions (Bergeron, 2000; Chen \& Popadiouk, 2002). However, variation in forest regeneration among stands experiencing the same disturbance type can also occur because of differences in local site conditions (Turner et al., 1997; Reyes \& Kneeshaw, 2008). For example, where advance regeneration is abundant, windthrow may cause only structural versus compositional changes in the tree canopy (Peterson, 2000; Reyes et al., 2010). Moreover, the sub-canopy tree and shrub community can display variation in responses to natural disturbances depending on light availability and level of soil disturbance; and depending on the relative speed of development and growth after disturbance, can ultimately impact the composition of the regenerating tree canopy (Gray et al., 2005; Hart \& Chen, 2006). Other local site factors such as pre-disturbance stand composition, physiography, and stand structural characteristics have been shown to affect woody vegetation diversity after natural disturbance at the stand scale (Dupont et al., 1991; Osumi et al., 2003; 
Rodriguez-Garcia et al., 2011). However, it is unclear if the same factors play key roles in determining re-vegetation patterns throughout an entire forest region. Factors can differ in importance among locations across a region, operate at local or regional scales, and can work synergistically to affect species diversity (Wimberly \& Spies, 2001; Hillebrand \& Blenckner, 2002; Huebner \& Vankat, 2003). Examining woody vegetation distribution after natural disturbances at various locations across a large, contiguous forest region dominated by the same canopy species can thus help to resolve potential contrasts by determining the different factors responsible for any observed variation across the region, for differences in responses to the same factors, or conversely, potentially link fine and broadscale vegetation recovery patterns to a few important factors that have consistent effects on woody species diversity across the region as a whole.

The purpose of our study is to document the relative importance of natural disturbances and local site factors on woody vegetation regeneration diversity among three, physiographically distinct locations across a large, contiguous forest ecosystem dominated by the same canopy species throughout. We specifically addressed the following questions: is the canopy composition maintained after disturbance or are different successional trajectories occurring? Does the type of natural disturbance determine woody species diversity or do local site factors more strongly influence regeneration distribution? Alternatively, do natural disturbances work synergistically with local site factors in determining woody species diversity? Lastly, do different combinations of disturbances and local site factors influence woody species diversity for specific locations or can a few common factors explain species distribution across the region? We hypothesized that given the physiographical differences among locations across the region, that different combinations of factors would be responsible for woody species diversity after natural disturbance at the local level; and consequently, that if different factors influence regeneration dynamics at local scales, it is likely that species diversity will differ across the region. Thus, although woody species diversity should be the highest at the regional scale, diversity should also reflect the intra-regional differences in disturbance history and the unique local site characteristics of these forests.

\section{Study Area}

The Abies balsamea-Betula spp. boreal mixedwood zone spans east to west across southern Quebec, Canada from $46^{\circ}$ to $50^{\circ} \mathrm{N}$ and $64^{\circ}$ to $80^{\circ} \mathrm{W}$ (Figure 1). It encompasses 23.8 million ha and represents $18.6 \%$ of the forested land of the province (MRNQ, 2003). The physiography of the region is highly variable. The western portion is continental, and is relatively flat to rolling. Topography becomes increasingly hilly to montane towards the east, as the eastern portion of the region includes the northeastern limit of the Appalachian mountain chain that runs southwest into the United States. The eastern portion also borders the Gulf of St. Lawrence, and thus contrasts with the western portion of the region by having a maritime influence. Elevations of forested areas range from 80 to $400 \mathrm{~m}$ in the west, and from sea level to $900 \mathrm{~m}$ in the east. Surface deposits are mostly glacial till or of lacustrine origin (Robitaille \& Saucier, 1998). The soil moisture regime is classified as xeric-mesic to mesic, while soil drainage ranges from imperfect to rapid.

Numerous disturbances such as fire, insect pests, and windthrow occur at varying frequency and severity in eastern boreal mixedwoods. The current return interval length for catastrophic

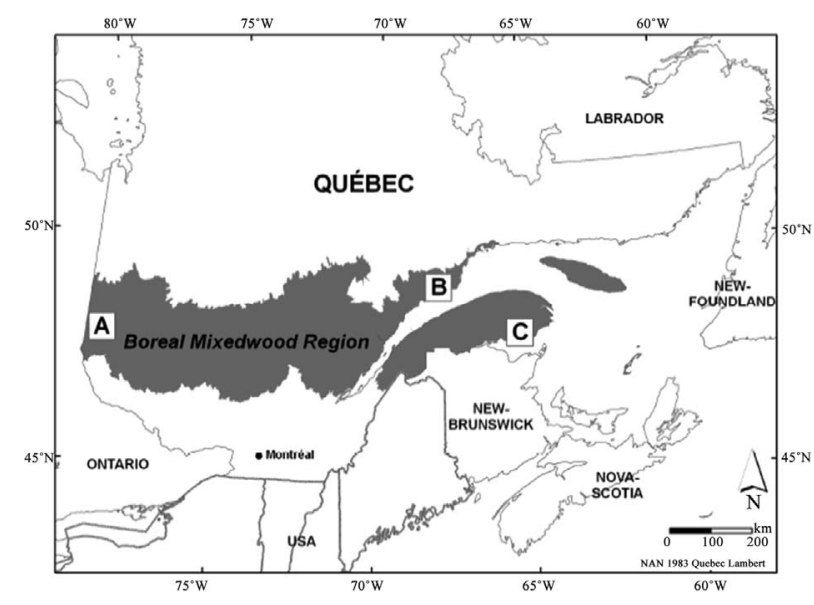

Figure 1.

Study locations within the boreal mixedwood region of Quebec, Canada. (A) continental-Abitibi-Temiskaming; (B) northern coastal-the North Shore; (C) southern coastal— the Gaspé Peninsula.

fires across the region ranges from 170 to 645 years (Bergeron et al., 2006), suggesting that less severe, but more frequent disturbances now assert greater influence on post-disturbance boreal mixedwood dynamics than in the recent past. Thus, we focused our attention on three types of non-fire disturbances that are common to boreal mixedwood forests: spruce budworm (Choristoneura fumiferana) outbreak, windthrow, and their interaction (nb., where a stand affected by spruce budworm outbreak is then subjected to windthrow prior to canopy recovery).

We sampled within three physiographically distinct, widely dispersed locations (between 200 and $500 \mathrm{~km}$ ) across the boreal mixedwood region of Quebec, Canada (Figure 1). The western sites are located in the Abitibi and Temiskaming municipalities $\left(77^{\circ} 30^{\prime}\right.$ to $79^{\circ} 10^{\prime} \mathrm{W}$ and $47^{\circ} 30^{\prime}$ to $48^{\circ} 20^{\prime} \mathrm{N}$ ). These sites have a flat to rolling topography and are influenced by continental climate conditions. The two eastern coastal locations both have hilly to rolling topography but differ mainly by latitude and elevation. The northern coastal sites are situated along the north shore of the St. Lawrence River, within the Haute Côte Nord and Manicouagan municipalities, and between $48^{\circ} 30^{\prime}$ to $50^{\circ} 00^{\prime}$ $\mathrm{N}$ and $68^{\circ} 00^{\prime}$ to $69^{\circ} 50^{\prime} \mathrm{W}$. Stands in this location are near the northern limit of the boreal mixedwood region. The southern coastal sites are situated within the southern part of the Gaspé Peninsula, along the Chaleur Bay area of the Atlantic Ocean (between $48^{\circ} 10^{\prime}$ to $48^{\circ} 35^{\prime} \mathrm{N}$ and $65^{\circ} 45^{\prime}$ to $66^{\circ} 15^{\prime} \mathrm{W}$ ). Other climate, physiographic, and forest structure and composition characteristics are compared among geographic locations in Table 1.

Relative species composition of the forest canopy can be quite variable within this forest type. We limited sampling to stands having two of the more common relative species compositions: stands were either conifer-dominated ( $\geq 75 \%$ density of conifers in canopy) or mixed coniferous-deciduous $(50 \%-74 \%$ density of conifers in canopy) prior to disturbance. In all cases, Abies balsamea, Betula papyrifera, and Betula alleghaniensis dominated the forest canopy prior to disturbance, and represented at least $60 \%$ of the coniferous and deciduous components within each stand, respectively. Picea glauca, Picea mariana, and Acer rubrum were also abundant in some sites while Thuja occidentalis, Pinus resinosa, Pinus strobus, Pinus 
Table 1.

Comparison of climate, physiographic, and forest structure and composition variables at each location using factorial ANOVA. Values in parentheses indicate \pm 1 Standard Error of the mean. Unlike letters along a row indicate values are significantly different among locations $(p<0.05)$.

\begin{tabular}{|c|c|c|c|}
\hline \multirow{2}{*}{ Variable } & \multicolumn{3}{|c|}{ Location } \\
\hline & Continental & Northern coastal & Southern coastal \\
\hline Annual rain $(\mathrm{mm})$ & $691.3(5.2) \mathbf{a}$ & $691.0(7.5) \mathbf{a}$ & $724.3(2.0) \mathbf{b}$ \\
\hline Annual snow (mm) & $274.3(6.2) \mathbf{a}$ & $303.4(4.5) \mathbf{b}$ & $238.6(0.6) \mathbf{c}$ \\
\hline Annual precipitation (mm) & 965.6 (11.4) ab & $988.9(10.3) \mathbf{b}$ & $963.1(1.4) \mathbf{a}$ \\
\hline Annual temperature $\left({ }^{\circ} \mathrm{C}\right)$ & $2.1(0.1) \mathbf{a}$ & $2.2(0.1) \mathbf{a}$ & $3.6(0.1) \mathbf{b}$ \\
\hline Mean monthly temperature-summer $\left({ }^{\circ} \mathrm{C}\right)$ & $16.3(0.1) \mathbf{a}$ & $15.3(0.1) \mathbf{a}$ & $16.6(0.1) \mathbf{a}$ \\
\hline Mean monthly temperature-winter $\left({ }^{\circ} \mathrm{C}\right)$ & $-10.4(0.1) \mathbf{a}$ & $-8.8(0.1) \mathbf{b}$ & $-7.3(0.1) \mathbf{c}$ \\
\hline Mean windspeed $\left(\mathrm{km} \cdot \mathrm{h}^{-1}\right)$ & $12.9(0.1) \mathbf{a}$ & $15.6(0.0) \mathbf{b}$ & $18.7(0.1) \mathbf{c}$ \\
\hline Maximum windspeed $\left(\mathrm{km} \cdot \mathrm{h}^{-1}\right)$ & $52.8(0.7) \mathbf{a}$ & $75.6(0.1) \mathbf{b}$ & $76.0(0.2) \mathbf{b}$ \\
\hline Maximum gust speed $\left(\mathrm{km} \cdot \mathrm{h}^{-1}\right)^{\dagger}$ & 98.4 & 105.2 & no data \\
\hline \multicolumn{4}{|l|}{ Physiography } \\
\hline Elevation (m) & $311.2(11.8) \mathbf{a}$ & $274.2(25.4) \mathbf{a}$ & $421.4(9.7) \mathbf{b}$ \\
\hline Slope $^{*}(\%)$ & $1.0(0.0) \mathbf{a}$ & $1.2(0.2) \mathbf{a}$ & $2.1(0.1) \mathbf{b}$ \\
\hline Latitude (degrees) & $47.3(0.1) \mathbf{a}$ & $49.0(0.1) \mathbf{b}$ & $48.5(2.3) \mathbf{b}$ \\
\hline Longitude (degrees) & $78.4(0.1) \mathbf{a}$ & $68.8(0.1) \mathbf{b}$ & $66.1(2.8) \mathbf{c}$ \\
\hline Soil drainage ${ }^{\dagger}$ & $3.5(0.2) \mathbf{a}$ & $3.1(0.2) \mathbf{a}$ & $2.3(0.1) \mathbf{b}$ \\
\hline \multicolumn{4}{|l|}{ Forest structure and composition } \\
\hline Mean disturbance area (ha) & $11.6(1.6) \mathbf{a b}$ & $8.9(1.7) \mathbf{a}$ & $13.2(1.0) \mathbf{b}$ \\
\hline Snag density $\left(\mathrm{ha}^{-1}\right)$ & $138.2(17.8) \mathbf{a}$ & $294.1(33.3) \mathbf{b}$ & $499.3(29.4) \mathbf{c}$ \\
\hline Course woody debris density $\left(\mathrm{ha}^{-1}\right)$ & $1176.4(10.9) \mathbf{a}$ & $1729.1(82.2) \mathbf{b}$ & $2159.9(105.2) \mathbf{c}$ \\
\hline Percentage of trees uprooted & $28.0(3.5) \mathbf{a}$ & $31.9(3.4) \mathbf{a}$ & $37.2(1.9) \mathbf{a}$ \\
\hline Decay class average & $11.2(0.1) \mathbf{a}$ & $11.2(0.1) \mathbf{a}$ & $10.4(0.1) \mathbf{b}$ \\
\hline Tree regeneration density $\left(\mathrm{ha}^{-1}\right)$ & $126+907.9(1936.6) \mathbf{a}$ & $36825.6(2593.6) \mathbf{b}$ & $15284.5(1525.3) \mathbf{a}$ \\
\hline Shrub regeneration density $\left(\mathrm{ha}^{-1}\right)$ & $11982.9(2288.1) \mathbf{a}$ & $33,969.6(3407.6) \mathbf{b}$ & $7454.0(732.1) \mathbf{a}$ \\
\hline Total regeneration density $\left(\mathrm{ha}^{-1}\right)$ & $24890.7(2043.0) \mathbf{a}$ & $70,895.2(3279.9) \mathbf{b}$ & $22738.6(1463.2)$ a \\
\hline Coniferous legacy tree density $\left(\mathrm{ha}^{-1}\right)$ & $1.3(.3) \mathbf{a}$ & $8.9(1.2) \mathbf{b}$ & $0.1(0.2) \mathbf{c}$ \\
\hline Deciduous legacy tree density $\left(\mathrm{ha}^{-1}\right)$ & $0.1(0.03) \mathbf{a}$ & $2.7(0.6) \mathbf{b}$ & $0.2(0.2) \mathbf{a}$ \\
\hline Crown cover of coniferous legacy trees (\%) & $3.5(0.8)$ a & $3.5(0.9)$ a & $4.2(1.0) \mathbf{a}$ \\
\hline Crown cover of deciduous legacy trees (\%) & $1.6(0.7)$ a & $1.7(0.6) \mathbf{a}$ & $6.8(1.2) \mathbf{b}$ \\
\hline Stand density prior to disturbance $\left(\mathrm{ha}^{-1}\right)$ & $926.6(89.3) \mathbf{a}$ & $1474.0(83.8) \mathbf{b}$ & $1718.7(80.7) \mathbf{b}$ \\
\hline
\end{tabular}

Note: ${ }^{\dagger}$ Insufficient data to include in analyses. ${ }^{*} 1: 0^{\circ}$ to $10^{\circ}, 2:>10^{\circ}$ to $20^{\circ}, 3:>20^{\circ}$ to $30^{\circ}, 4:>30^{\circ}$ to $40^{\circ}, 5:>40^{\circ} ;{ }^{\dagger} 2$ : good, $3:$ moderate; 4 : imperfect; ${ }^{\star}$ See Imbeau \& Desrochers (2002).

banksiana, Larix laricina, Acer saccharum, Fraxinus americana, Fraxinus nigra, Populus balsamifera, and Populus tremuloides were occasionally present.

\section{Sampling Methods}

Disturbance type, climate, and physiographical data were derived from digitised aerial photos, eco-forestry maps, or sourced from various provincial and federal government agencies (MNRQ, 2003; Environment Canada, 2004), with the exception of slope and elevation, which were determined on site using a clinometer and GPS unit, respectively. A total of 76 sites affected by spruce budworm outbreak, windthrow, or their interaction were examined: 24, 22, and 30 sites for the continental (Abitibi-Temiskaming), northern coastal (North Shore), and southern coastal (Gaspé Peninsula) locations, respectively. 
Up to six $20 \times 20 \mathrm{~m}$ quadrats were sampled within each disturbed site. We limited our sampling to mature stands $(\geq 80$ years old-verified within each site by counting annual rings of remnant trees or old stumps) having at least 0.2 ha of contiguous canopy mortality to reduce variation resulting from differences in stand age, disturbance severity, and the spatial extent of disturbance. Further, all quadrats were at least $40 \mathrm{~m}$ from the nearest intact forest and $30 \mathrm{~m}$ from the nearest logging road to avoid edge effects.

Density of tree and shrub regeneration was quantified within each quadrat for three size classes: (1) 1 to $2 \mathrm{~m}$ tall, (2) $>2 \mathrm{~m}$ tall and $<4 \mathrm{~cm}$ dbh $(1.37 \mathrm{~cm})$, and (3) between 4 and $8 \mathrm{~cm} \mathrm{dbh}$ using a nested plot design. Different height classes were used to determine which individuals were more or less likely to be recruited into the canopy. Some species in the region such as Abies balsamea can produce $1000 \mathrm{~s}$ of regenerating seedlings per hectare, many of which remain suppressed even after canopy disturbance (Reyes \& Kneeshaw, 2008). Class 1 regeneration was sampled in a $2 \times 10 \mathrm{~m}$ area, class 2 in a $5 \times 10 \mathrm{~m}$ area, and class 3 within the entire quadrat. Density of snags (standing dead trees $>10 \mathrm{~cm} \mathrm{dbh}$ ) and coarse woody debris (downed trees $>10 \mathrm{~cm} \mathrm{dbh}$ ) were determined and classified using a modified decay classification scale developed by Imbeau \& Desrochers (2002). Coarse woody debris was also categorised as uprooted or snapped when possible; n.b., past research has shown that certain boreal species establish better in exposed mineral soils versus other substrates (Kuuluvainen \& Juntunen, 1998). Thus, if more coarse woody debris is uprooted versus snapped, then one could expect a greater proportion of these types of species as well. Crown cover $\left(\mathrm{m}^{2}\right)$ of legacy trees (mature overstory trees that survived the natural disturbance) within each quadrat, and density of deciduous and coniferous legacy trees within a $35 \mathrm{~m}$ radius of the quadrat centre were also determined. This was done to provide some indication of the amount of shade available to the regeneration, which can thus potentially influence what species regenerate in close proximity, and provide information on potential sources of seed rain, respectively.

\section{Analyses}

Various analyses were used to compare and contrast woody vegetation diversity after natural disturbance between the continental, northern coastal, and southern coastal locations. Comparisons of the climate, physiographic, and forest structure and composition characteristics that were quantified for each location were made using analysis of variance (ANOVA) (SPSS $10.0,1999)$ followed by the Student-Newman-Keuls multiple range test when significant differences were observed (at $p<$ 0.05) (Table 1).

\section{Direct Gradient Analyses}

We used a series of redundancy analyses (RDA) (van den Wollenberg, 1977) to examine the relationships between local site factors (i.e., the various disturbance types, climate, physicographic, and stand structure and composition variables) and woody vegetation species distribution for each of the three study locations. For each analysis, the forward selection option was implemented to both rank the importance of each site factor variable and to exclude redundant and non-significant variables from the model. The significance of the explanatory effect of a site factor variable was determined using a Monte Carlo permutation test (200 permutations, $p<0.05$ ) prior to the addi- tion of the next best fitting variable. CANOCO 4.0 software (ter Braak \& Smilauer, 1998) was used to run the analyses. Variables were centred and standardized as the site factor variables were measured using different units.

\section{Species Diversity Estimates}

Five measures of species diversity were calculated at two spatial scales: for both the entire study region and for each of the three study locations (continental, northern coastal, southern coastal). Thus, comparisons between regional and local diversity levels, as well as among the three study locations could be made. Calculations were also made for the entire woody vegetation community and for each of the woody vegetation layers separately; i.e., canopy tree regeneration versus sub-canopy tree $\&$ shrub regeneration. This was done as different disturbance types can affect the understory community differently (Veblen \& Ashton, 1978; Hart \& Chen, 2006). Thus, diversity of the canopy tree regeneration may be influenced by the sub-canopy tree and shrub community that survived the disturbance or by sub-canopy species that can quickly establish soon after (Gray et al., 2005).

Regional level species diversity estimates were the following: alpha diversity $(\alpha)$ represented mean site level richness, beta diversity $(\beta)$ represented differences in richness among sites across the study region; i.e., the differences in species composition among spatial units, while gamma diversity $(\gamma)$ represented the total richness across the study region (Whittaker, 1960; Novotny \& Weiblen, 2005). Beta diversity (Whittaker, 1960) was computed as:

$$
\beta=(\gamma / \alpha)-1
$$

Shannon's diversity index (Shannon \& Weaver, 1949):

$$
H^{\prime}=-\sum p_{i} \ln p_{i}
$$

where $p_{i}=$ proportion of the total sample belonging to species $i$ (in our case, the relative density of a species), and evenness $(J)$ :

$$
J=H^{\prime} / \ln \alpha
$$

where $J$ is an index of how relative abundances of species are distributed (Pielou, 1966), were determined for each regeneration layer for each site. Analysis of variance followed by the Student-Newman-Keuls multiple range tests were used to compare the various diversity estimates among study locations and vegetation layers $(p<0.05)$.

Species richness is partly a function of spatial scale (Palmer \& White 1994). We acknowledge that differences in richness could be an artifact of sampling effort among locations. The total disturbed area examined for the continental, northern coastal, and southern coastal sites were 405.2, 505.6, and 1238.3 ha, respectively. We sampled the three locations using 35,57 , and 95 quadrats, respectively, to make sampling effort more equitable among locations. However, bias in species richness may also occur due to the unequal number of quadrats. Sample rarefaction (Krebs, 1989) was used to compute a species accumulation curve as a function of the number of quadrats examined for each location. PAST version 1.94b (Hammer et al., 2001) was used to run analysis. Results show that differences in species richness due to differences in the number of quadrats examined in each location was negligible (Figure 2). Thus, we felt that making comparisons of diversity estimates among the three locations using our sampling protocol was a valid undertaking. 




Figure 2.

Sample rarefaction analysis to determine if differences in species richness estimates were associated with variation in sampling effort. A total of 35,57 , and 95 quadrats $(20 \times 20 \mathrm{~m})$ were used in the continental, northern coastal, and southern coastal locations, respectively. Curves (in blue) above and below mean species values represent $95 \%$ confidence intervals.

\section{Results}

\section{Factors Influencing Vegetation Distribution across the Forest Region}

Disturbance type was not the primary driver of species distribution patterns in all locations across the boreal mixedwood region. The different disturbance types had only a minor influence on regeneration distribution in the coastal sites, whereas windthrow produced distinctive woody vegetation distribution patterns in the continental sites (Table 2). There was no common group of variables that influenced regeneration distribution at all locations. Different combinations of factors strongly influenced woody vegetation regeneration at each location (Table 2). In decreasing order of importance, woody vegetation distribution in the continental sites was primarily driven by windthrow, annual rainfall, and coarse woody debris density. Species distribution for the northern coastal sites were most strongly associated with latitude, elevation, annual rainfall, coarse woody debris density, and windthrow, while species distribution in the southern coastal sites were associated mostly by stand composition prior to disturbance, coarse woody debris density, decay class, spruce budworm outbreak, and elevation (Table 2, Figure 3). Coarse woody debris density was the sole factor affecting distribution patterns in all locations, ac counting for a large proportion of the variation throughout the boreal

\section{Table 2.}

Canonical correlation coefficients between significant environmental variables and the first four ordination axes for redundancy analysis examining species-environment relationships for each study location ( $p<0.05$; ns indicates non-significance).

\begin{tabular}{|c|c|c|c|c|}
\hline \multirow{2}{*}{ Location \& Environmental Variable } & \multicolumn{2}{|c|}{ Axis } & \multirow[b]{2}{*}{3} & \multirow[b]{2}{*}{4} \\
\hline & 1 & 2 & & \\
\hline \multicolumn{5}{|l|}{ Continental } \\
\hline Windthrow & -0.70 & -0.33 & ns & ns \\
\hline Annual rainfall (mm) & 0.75 & -0.39 & ns & ns \\
\hline Coarse woody debris density $\left(\mathrm{ha}^{-1}\right)$ & 0.27 & $\mathrm{~ns}$ & -0.66 & ns \\
\hline \multicolumn{5}{|l|}{ Northern coastal } \\
\hline Latitude & 0.57 & $\mathrm{~ns}$ & ns & ns \\
\hline Elevation (m) & -0.18 & $\mathrm{~ns}$ & 0.24 & 0.39 \\
\hline Annual rainfall $(\mathrm{mm})$ & -0.19 & 0.35 & ns & ns \\
\hline Coarse woody debris density $\left(\mathrm{ha}^{-1}\right)$ & ns & 0.24 & -0.25 & 0.39 \\
\hline Windthrow & -0.10 & -0.01 & -0.43 & ns \\
\hline \multicolumn{5}{|l|}{ Southern coastal } \\
\hline Conifer-dominated stand prior to disturbance & 0.54 & $\mathrm{~ns}$ & $\mathrm{~ns}$ & $\mathrm{~ns}$ \\
\hline Coarse woody debris density $\left(\mathrm{ha}^{-1}\right)$ & 00.51 & ns & -0.30 & ns \\
\hline Decay class & -0.29 & -0.34 & -0.31 & ns \\
\hline Spruce budworm outbreak & 00.28 & $\mathrm{~ns}$ & ns & 0.30 \\
\hline Elevation (m) & ns & -0.44 & ns & ns \\
\hline
\end{tabular}



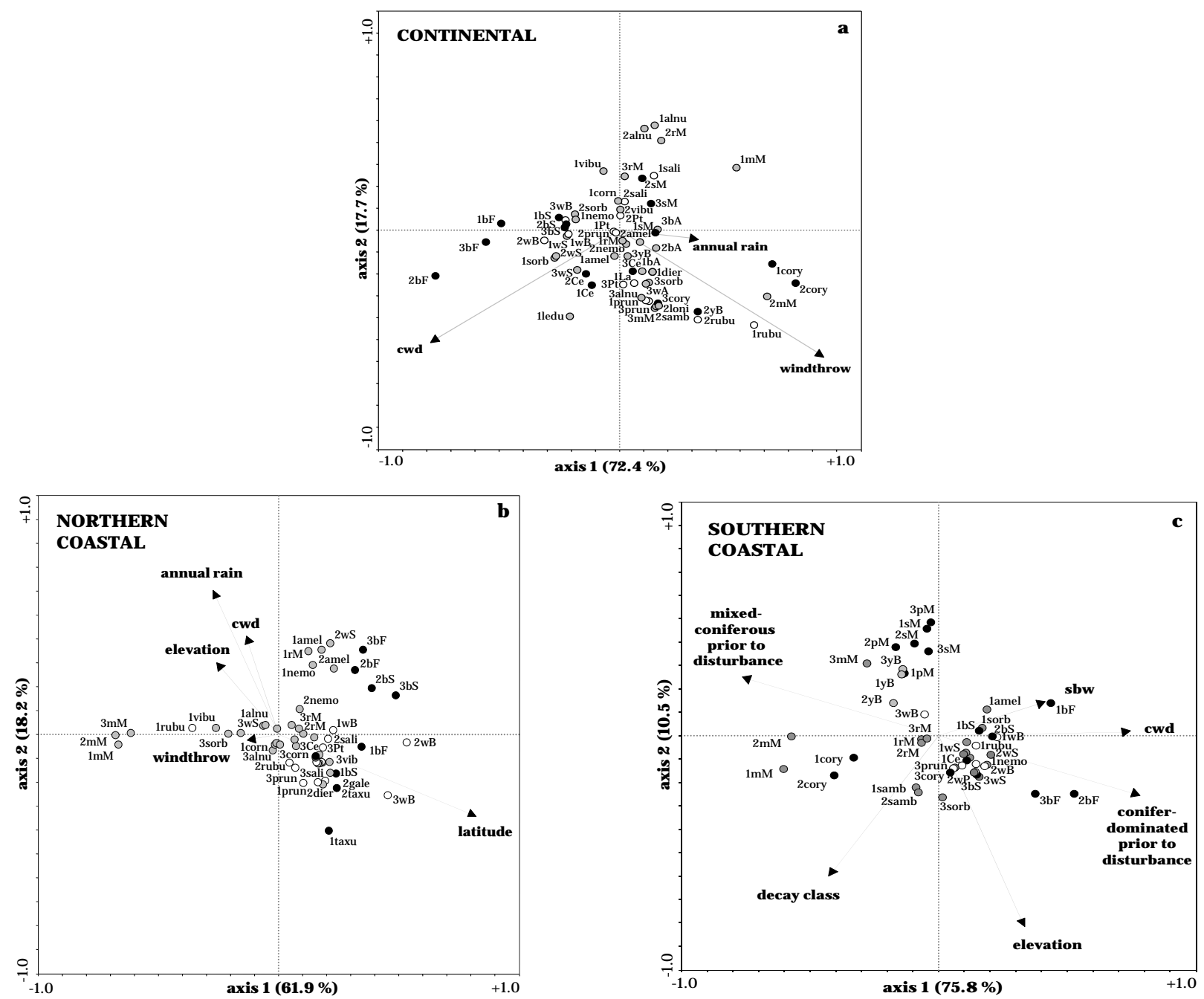

Figure 3.

Examination of woody vegetation distribution patterns for three locations within the boreal mixedwood region of Quebec, Canada in relation to disturbance type, climate, physiography, and stand structure and composition variables using Redundancy analysis (RDA). The first two canonical axes in RDA explained $27.2 \%$ and $6.6 \%, 15.3 \%$ and $4.5 \%$, and $18.2 \%$ and $2.6 \%$ of the cumulative variance in the species data for the continental, northern coastal, and southern coastal sites, respectively. Length and position of vectors and points from the origin in relation to axes 1 and 2 indicate strength of relationships among variables in ordination space, where greater distances from the origin in conjunction with closer positions to either axis 1 or 2 indicate stronger associations. Only the environmental variables having significant relationships with axes 1 or 2 are shown. Some species names near the origin were removed to reduce clutter. Numbers preceding species codes indicate the following regeneration size classes: (1) 1 to $2 \mathrm{~m}$ tall, (2) $>2 \mathrm{~m}$ tall and $<4 \mathrm{~cm}$ dbh $(1.37 \mathrm{~m})$, (3) 4 to $8 \mathrm{~cm}$ dbh. Species and environmental variable codes are as follows: $\mathrm{wA}=$ Fraxinus americanus, $\mathrm{bA}=$ Fraxinus nigra, $\mathrm{wB}=$ Betula papyrifera, $\mathrm{yB}=$ Betula alleghaniensis, Ce $=$ Thuja occidentalis, $\mathrm{bF}=$ Abies balsamea, $\mathrm{La}=$ Larix laricina, $\mathrm{mM}=$ Acer spicatum, $\mathrm{pM}=$ Acer pensylvanicum, $\mathrm{rM}=$ Acer rubrum, $\mathrm{sM}=$ Acer saccharum, $\mathrm{Pt}=$ Populus tremuloides, $\mathrm{wP}=$ Pinus strobus, $\mathrm{bS}=$ Picea mariana, $\mathrm{wS}=$ Picea glauca, $\mathrm{alnu}=$ Alnus spp., amel = Amelanchier spp., corn = Cornus stolonifera, cory $=$ Corylus cornuta, dier $=$ Diervella lonicera, gale $=$ Myrica gale, $\mathrm{kalm}=$ Kalmia angustifolia, ledu $=$ Ledum groenlandicum, loni $=$ Lonicera spp., nemo = Nemopanthus mucronata, prun = Prunusspp., rubu = Rubus spp., sali = Salix spp., samb = Sambucus spp., sorb $=$ Sorbus spp., vibe $=$ Viburnum edule, vibu $=$ Viburnum cassinoides, taxu $=$ Taxus canadensis, $\mathrm{BF}-\mathrm{WB}=$ Abies balsamea-Betula papyrifera Ecozone, $\mathrm{BF}-\mathrm{YB}=$ A. balsamea-B. alleghaniensis Ecozone, and cwd = coarse woody debris. Shade tolerance: $\bullet$ high, $\bigcirc$ mid, $\bigcirc$ low.

mixedwood region. Further, all height classes of each species generally responded in the same manner, indicated by the clustering of intra-specific species points in the biplots (Figure 3).

\section{Species Diversity across the Region}

A total of 33 woody species were observed in the system (12 canopy trees, 21 sub-canopy tree and shrubs) (Table 3). No species were considered rare or endangered. Relative abundances of Abies balsamea, Betula papyrifera, and Betula al- leghaniensis, the dominant coniferous and deciduous species in the system, were generally maintained, although the northern coastal sites had increases in the coniferous component relative to pre-disturbance conditions in mixed-coniferous stands (Figure 4). Cyclical regeneration patterns occurred in stands that were conifer-dominated prior to disturbance as Abies balsamea, a shade-tolerant conifer species, dominated the regeneration layer (Figure 4, Table 3). Stands that were mixed-coniferous prior to disturbance maintained their deciduous canopy tree components, while deciduous sub-canopy tree and shrub com- 


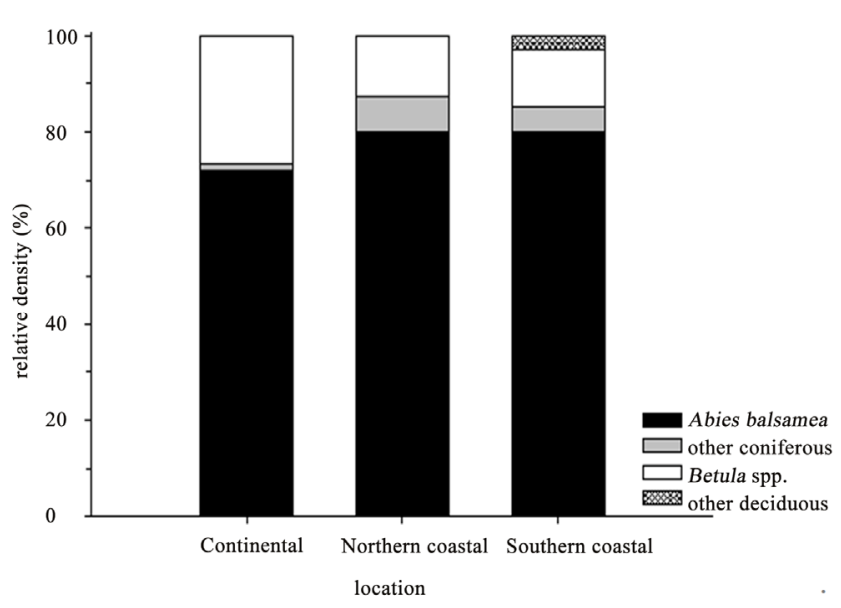

(a)

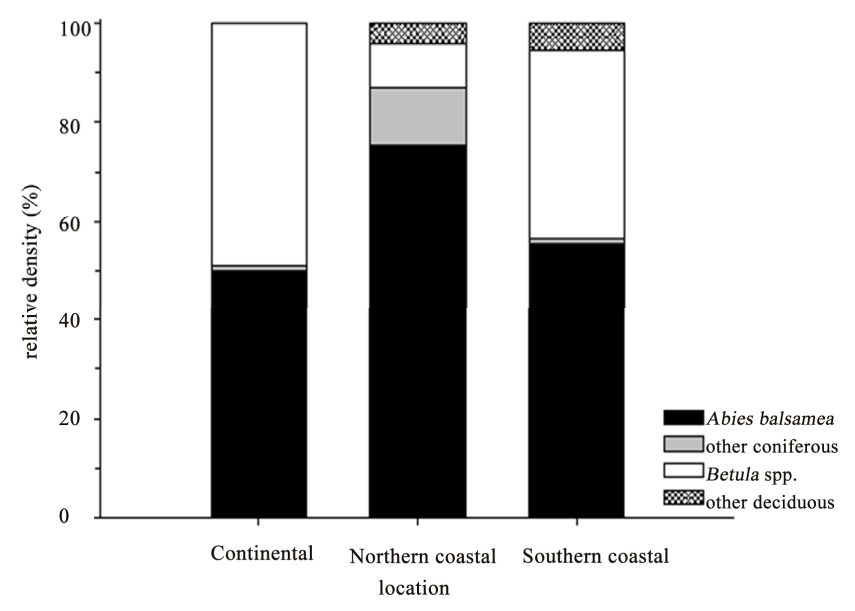

(b)

Figure 4.

Relative densities of principal canopy tree species regeneration for each location within the boreal mixedwood study region for (a) conifer-dominated stands ( $\geq 75 \%$ conifer canopy prior to disturbance) and (b) mixed-coniferous stands ( $50 \%-74 \%$ conifer canopy) prior to disturbance.

petitors such as Acer spicatum and Corylus cornuta were more abundant there. Shade-tolerant conifer tree species were strongly associated with high densities of coarse woody debris. However, Betula papyrifera, a shade-intolerant deciduous species, was able to maintain its relative abundance in stands that were conifer-dominated prior to disturbance, and was able to establish in areas with high coarse woody debris densities. Closer examination showed that most of the Betula papyrifera regeneration was restricted to microsites with exposed mineral soils resulting from tree uprooting (G. Reyes, personal observation).

\section{Comparing Species Diversity among Locations}

Alpha $(\alpha)$ diversity for canopy tree species was similar at all locations throughout the region $(p>0.05)$ (Table 4). Alpha diversity for total woody vegetation regeneration and for subcanopy tree and shrub regeneration was higher in the northern coastal versus the southern coastal sites $(p<0.05)$ while $\alpha$ diversity in the continental sites was intermediate between the other two locations and did not significantly differ from either coastal location $(p>0.05)$. Beta $(\beta)$ diversity for all vegetation layers was generally higher in the continental sites, indicating greater variation in species diversity among sites there. This coincided with the continental sites having the largest species pool among the three locations (n.b., 28 woody species observed Table 4), as gamma $(\gamma)$ diversity was the highest there for all vegetation layers. Shannon's diversity index $\left(H^{\prime}\right)$ was similar among locations for total woody vegetation and for the canopy tree layer $(p>0.05)$. Sub-canopy tree and shrub $H^{\prime}$ was greater in the northern coastal versus the southern coastal locations $(p<0.05)$. Dominance by certain canopy tree species was more prevalent in the northern versus southern coastal locations, as indicated by the lower evenness $(J)$ estimates $(p<0.05)$. Indeed, the majority of the canopy tree regeneration in the northern coastal sites consisted of either Abies balsamea, Picea mariana, or Betula papyrifera (Table 3). The continental sites had intermediate $J$ values and did not differ from either coastal location. Alpha, $\beta, \gamma$, and $H^{\prime}$ values were greater for the sub-canopy tree and shrub layer relative to the canopy tree regeneration within and among all geographical locations and for across the region as a whole.

\section{Discussion}

\section{Factors Influencing Vegetation Distribution across the Forest Region}

While different factors influenced post-disturbance community composition among locations across the region, relative species compositions of the tree canopy were either maintained or were developing towards dominance by the shade-tolerant conifer, Abies balsamea. The likely mechanisms by which this is occurring are via the competitive advantage provided by an abundant advance regeneration layer and the protection provided by coarse woody debris.

Because the disturbances examined here did not cause extensive damage to the understory vegetation present prior to disturbance, stand composition after natural disturbance was dominated by Abies balsamea, a species that develops an abundant advance regeneration layer over time (Morin, 1994). The presence of advance regeneration reduced the ability of shade-intolerant deciduous species to establish after natural disturbance by limiting available growing space, light, and other resources (Morin et al., 2008).

Density of coarse woody debris was the only environmental factor significantly affecting regeneration patterns across the entire region. Its irregular spatial distribution and variation in level of decay throughout the landscape was important for the creation of stand heterogeneity, to which the various species responded. For example, shade-tolerant conifer tree species such as Abies balsamea and Picea mariana dominated areas where the density of coarse woody debris was high. Coarse woody debris was beneficial for the survival of the advance regeneration perhaps by mitigating the adverse changes in microsite conditions after disturbance by providing cover and shade (Gray \& Spies, 1997; Elliott et al., 2002). Consequently, cyclical regeneration patterns (Baskerville, 1975) were observed in conifer-dominated stands. Conversely, areas where coarse woody debris densities were low or where it was absent altogether allowed for the establishment of more shade-intolerant deciduous species such as Populus tremuloides, Betula 
Table 3.

Mean regeneration density $\left(\mathrm{ha}^{-1}\right)$ for woody species establishing within the boreal mixedwood region of Quebec, Canada. Shade tolerance: high, O mid, $\mathrm{O}$ low.

\begin{tabular}{|c|c|c|c|}
\hline \multirow{2}{*}{ Species } & \multicolumn{3}{|c|}{ Location } \\
\hline & Continental & Northern coastal & Southern coastal \\
\hline \multicolumn{4}{|l|}{ Canopy trees } \\
\hline Abies balsamea & 2576.1 & 7427.8 & 2714.7 \\
\hline Picea mariana & 194.3 & 459.8 & 22.5 \\
\hline Thuja occidentalis & 22.9 & 1.0 & 0.8 \\
\hline Acer saccharum & 21.4 & - & - \\
\hline Picea glauca $\bigcirc$ & 73.7 & 211.7 & 25.1 \\
\hline Betula alleghaniensis $\bigcirc$ & 7.3 & - & 183.1 \\
\hline Pinus strobes $\bigcirc$ & - & - & 2.1 \\
\hline Fraxinus americanus $\bigcirc$ & 1.4 & - & - \\
\hline Fraxinus nigra $\bigcirc$ & 8.6 & - & - \\
\hline Larix laricina $\bigcirc$ & 1.4 & - & - \\
\hline Betula papyrifera $\bigcirc$ & 268.9 & 1103.4 & 856.7 \\
\hline Populus tremuloides $\bigcirc$ & 50.3 & 2.8 & 16.2 \\
\hline \multicolumn{4}{|l|}{ Sub-canopy trees \& shrubs } \\
\hline Acer pensylvanicum & - & - & 38.0 \\
\hline Corylus cornuta & 1004.5 & - & 169.0 \\
\hline Taxus canadensis & - & 1170.6 & - \\
\hline Acer rubrum $\bigcirc$ & 44.3 & 90.4 & 98.3 \\
\hline Acer spicatum $\bigcirc$ & 491.8 & 3011.0 & 884.0 \\
\hline Alnus spp. $\bigcirc$ & 437.9 & 525.1 & - \\
\hline Amelanchier spp. $\bigcirc$ & 21.4 & 686.5 & 204.2 \\
\hline Cornus stolonifera $\bigcirc$ & 15.7 & 104.4 & 2.1 \\
\hline Diervella lonicera $\bigcirc$ & 1.4 & 58.3 & - \\
\hline Kalmia angustifolium $\bigcirc$ & - & 318.9 & - \\
\hline Ledum groenlandicum $\bigcirc$ & 5.7 & 26.3 & - \\
\hline Lonicera spp. $\bigcirc$ & 1.4 & - & - \\
\hline Myrica gale $\bigcirc$ & - & 31.6 & - \\
\hline Nemopanthus mucronata $\bigcirc$ & 90 & 30.3 & 3.7 \\
\hline Sambucus spp. $\bigcirc$ & 1.4 & - & 18.9 \\
\hline Sorbus spp. $\bigcirc$ & 197.1 & 641.7 & 348.3 \\
\hline Viburnum cassinoides $\bigcirc$ & 40.0 & - & - \\
\hline Viburnum edule $\bigcirc$ & 236.4 & 486.8 & - \\
\hline Prunus spp. $\bigcirc$ & 66.6 & 72.5 & 83.3 \\
\hline Rubus spp. $\bigcirc$ & 302.8 & 1236.8 & 13.7 \\
\hline Salix spp. $\bigcirc$ & 37.1 & 1.3 & - \\
\hline
\end{tabular}


Table 4.

Estimates of alpha $(\alpha)$, beta $(\beta)$, gamma $(\gamma)$, Shannon's $\left(H^{\prime}\right)$ and evenness $(J)$ diversity indices according to location and regeneration layer. Testing for differences in $\alpha, H^{\prime}$, and $\mathrm{J}$ among locations for each vegetation layer was made using ANOVA. Within a column, values with post-script indicate significant differences were observed for the particular vegetation layer-where unlike letters among locations for the vegetation layer in question indicate significant differences at $p<0.05$. Values in parentheses indicate \pm 1 Standard Error of the mean.

\begin{tabular}{|c|c|c|c|c|c|}
\hline \multirow{2}{*}{ Location \& vegetation layer } & \multirow[b]{2}{*}{$\alpha$} & \multirow[b]{2}{*}{$\beta$} & \multirow[b]{2}{*}{$\gamma$} & \multicolumn{2}{|c|}{ Indice } \\
\hline & & & & $H^{\prime}$ & $J$ \\
\hline \multicolumn{6}{|l|}{ Continental } \\
\hline All woody vegetation & $8.5(0.5) \mathbf{a b}$ & 2.3 & 28 & $1.3(0.1)$ & $0.5(0.1)$ \\
\hline Canopy trees & $3.7(0.2)$ & 1.9 & 11 & $0.6(0.1)$ & $0.5(0.1) \mathrm{ab}$ \\
\hline Sub-canopy tree $\&$ shrubs & $4.7(0.4) \mathbf{a b}$ & 2.6 & 17 & $1.0(0.1) \mathbf{a b}$ & $0.7(0.1)$ \\
\hline \multicolumn{6}{|l|}{ Northern coastal } \\
\hline All woody vegetation & $9.2(0.5) \mathbf{a}$ & 1.4 & 22 & $1.4(0.1)$ & $0.5(0.1)$ \\
\hline Canopy trees & $3.7(0.2)$ & 0.6 & 6 & $0.7(0.1)$ & $0.4(0.1) \mathbf{a}$ \\
\hline Sub-canopy tree $\&$ shrubs & $5.8(0.4) \mathbf{a}$ & 1.8 & 16 & $1.1(0.1) \mathbf{a}$ & $0.6(0.1)$ \\
\hline \multicolumn{6}{|l|}{ Southern coastal } \\
\hline All woody vegetation & $7.5(0.4) \mathbf{b}$ & 1.5 & 19 & $1.2(0.1)$ & $0.5(0.1)$ \\
\hline Canopy trees & $3.4(0.2)$ & 1.4 & 8 & $0.7(0.1)$ & $0.6(0.1) \mathbf{b}$ \\
\hline Sub-canopy tree $\&$ shrubs & $4.1(0.4) \mathbf{b}$ & 1.7 & 11 & $0.8(0.1) \mathbf{b}$ & $0.6(0.1)$ \\
\hline \multicolumn{6}{|l|}{ Regional } \\
\hline All woody vegetation & 8.3 & 3.0 & 33 & 1.3 & 0.5 \\
\hline Canopy trees & 3.6 & 2.3 & 12 & 0.6 & 0.6 \\
\hline Sub-canopy tree $\&$ shrubs & 4.8 & 3.4 & 21 & 1.0 & 0.6 \\
\hline
\end{tabular}

spp., and Acer spicatum. Retaining a deciduous tree canopy component in areas with a high density of coarse woody debris was also observed, but was mostly restricted to microsites with exposed mineral soils resulting from tree uprooting. Uprooting occurred in approximately $1 / 3$ of all tree mortality throughout the region, and accordingly, may be an important mechanism for maintaining the proportion of Betula spp. and other shadeintolerant species across the landscape.

Mixed-coniferous stands either maintained their relative coniferous-deciduous species ratios or increased in the deciduous component. However, much of this increase was related to greater densities of deciduous sub-canopy tree and shrub species. The influx of sub-canopy tree and shrub species can temporarily alter species composition ratios relative to pre-disturbance conditions and/or delay canopy development for a number of years (Hart \& Chen, 2006), but will have little effect on canopy species composition once the tree canopy grows beyond a few metres in height. In fact, when considering only the tree canopy regeneration, mixed-coniferous stands generally maintained their pre-disturbance relative coniferous-deciduous species ratios or displayed increases in the conifer component.

\section{Species Diversity across the Region}

Differences in species diversity among locations was largely due greater gamma $(\gamma)$ diversity in the tree canopy layer in continental sites relative to coastal sites, and to variation in the sub-canopy tree and shrub layer $\gamma$ diversity among coastal locations. The greater degree of variation in the sub-canopy and shrub component in the coastal locations suggests that these species were more sensitive to differences in local site conditions while canopy tree species had a wider range of habitat tolerances. This is shown via the lower beta $(\beta)$ diversity values for canopy trees versus sub-canopy trees and shrubs in all locations.

Comparing regional $\gamma$ diversity versus $\gamma$ diversity at each location suggests that the continental sites were more limited by the regional species pool, whereas local processes and conditions were important limiting factors in the coastal sites. Only five of the 33 species observed throughout the region were not observed in continental sites whereas 11 and 14 species were absent in the northern and southern coastal sites, respectively. Thus, it appears that a broader depth of habitat types is available in the continental sites relative to coastal locales. This is corroborated by the highest $\beta$ diversity being observed in the continental sites, followed by the northern coastal then southern coastal sites.

Previous studies have reported a $\beta$ diversity-latitude gradient of decreasing values from south to north (Qian \& Ricklefs, 2007; Lenoir et al., 2010). Similar patterns were observed here for the canopy tree layer and for total woody vegetation as $\beta$ diversity was greatest in the continental areas (lowest latitudes) and lowest in the northern coastal locations (the highest latitudes). The sub-canopy tree $\&$ shrub layer did not follow this 
pattern as $\beta$ diversity was higher in the northern versus southern coastal sites. Further, $\alpha$ and $\gamma$ diversity for sub-canopy tree \& shrubs did not follow this latitudinal pattern along the coast either, as these diversity components were also higher in northern coastal sites. Other site-level factors, such as density of coarse woody debris may have been important in influencing regeneration distribution. Differences in $\beta$ diversity among locations coincided with coarse woody debris and snag densities being lowest in the continental sites and the highest in the southern coastal sites, which would suggest greater availability of growing space in the continental areas and lowest available space in the southern coastal sites.

\section{Conclusion}

The effects of windthrow, spruce budworm, and interaction natural disturbances on local site conditions were not severe enough to alter canopy species dominance. Dominance by the main canopy species, Abies balsamea and Betula spp. was maintained throughout the region, suggesting that these species had a wider tolerance range and wider niche overlap relative to other woody species, and/or that the severity of these natural disturbances wasn't sufficient to alter succession trajectories. Moreover, differences in the importance of factors influencing responses of the woody vegetation among locations across the boreal mixedwood region reinforces the concept that species distribution is not controlled by natural disturbance alone, but that local environmental characteristics and constraints on plant biology also dictate re-establishment success. Each location across the region had different and unique site characteristics, and accordingly, species composition and abundance varied from one location to the next. Thus, while the specific disturbance types did not considerably alter canopy tree composition, as development towards old-growth, conifer-dominated conditions was maintained, these natural disturbances were important for creating a mosaic of structural legacies that promote stand heterogeneity, which can ultimately help to maintain biodiversity in the region.

\section{Acknowledgements}

Many thanks to all my field assistants (J.-F. Mnudles-Gagnon, Maude Beauregard, David Saucier, Julie Messierer, and Isabelle Nault). Your various personalities, quirks, and habits that were amplified during long, buggy, hot and/or rainy days in the field made data collection quite memorable and fun! Additionally, this study would not have been possible without financial and/or technical support from TEMREX, NSERCCFS and the SFMN.

\section{REFERENCES}

Baskerville, G. L. (1975). Spruce budworm: Super silviculturist. The Forestry Chronicle, 51, 138-140.

Belote, R. T., Sanders, N. J., \& Jones, R. H. (2009). Disturbance alters local-regional richness relationships in Appalachian forests. Ecology, 90, 2940-2947. doi:10.1890/08-1908.1

Bergeron, Y. (2000). Species and stand dynamics in the mixed woods of Quebec's southern boreal forest. Ecology, 81, 1500-1516. doi:10.1890/0012-9658(2000)081[1500:SASDIT]2.0.CO;2

Bergeron, Y., Cyr, D., Drever, R., Flannigan, M., Gauthier, S., Kneeshaw, D., Lauzon, E., Leduc, A., Le Goff, H., Lesieur, D., \& Logan, K. (2006). Past, current, and future fire frequencies in Quebec's commercial forests: Implications for the cumulative effects of har- vesting and fire on age-class structure and natural disturbance-based management. Canadian Journal of Forest Research, 36, 2737-2744. doi:10.1139/x06-177

Chen, H. Y. H., \& Popadiouk, R. V. (2002). Dynamics of North American boreal mixedwoods. Environmental Reviews, 10, 137-166. doi:10.1139/a02-007

Dansereau, P. (1954). Climax vegetation and the regional shift of controls. Ecology, 35, 575-579. doi:10.2307/1931048

Dupont, A., Belanger, L., \& Bousquet, J. (1991). Relationships between balsam fir vulnerability to spruce budworm and ecological site conditions of fir stands in central Quebec. Canadian Journal of Forest Research, 21, 1752-1759. doi:10.1139/x91-242

Elliott, K. J., Hitchcock, H. L., \& Krueger, L. (2002). Vegetation response to large scale disturbance in a southern Appalachian forest: Hurricane Opal and salvage logging. Journal of the Torrey Botanical Society, 129, 48-59. doi:10.2307/3088682

Environment Canada (2004). Canadian climate normals or averages 1971-2000. URL (last checked 24 July 2006).

http://climate.weatheroffice.ec.gc.ca/climate normals/index e.html

Gray, A. N., \& Spies, T. A. (1997). Microsite controls on tree seedling establishment in conifer forest canopy gaps. Ecology, 78, 2458-2473. doi:10.1890/0012-9658(1997)078[2458:MCOTSE]2.0.CO;2

Gray, A. N., Zald, H. S. J., Kern, R. A., \& North, M. (2005). Stand conditions associated with tree regeneration in sierran mixed-conifer forests. Forest Science, 51, 198-210.

Gromtsev, A. (2002). Natural disturbance dynamics in the boreal forests of European Russia: A review. Silva Fennica, 36, 41-55.

Hammer, O., Harper, D. A. T., \& Ryan, P. D. (2001). PAST: Paleontological statistics software package for education and data analysis. Palaeontologia Electronica, 4, 1-9.

Hart, S. A., \& Chen, H. Y. H. (2006). Understory vegetation dynamics of North American boreal forests. Critical Reviews in Plant Sciences, 25, 381-397. doi:10.1080/07352680600819286

Hillebrand, H., \& Blenckner, T. (2002). Regional and local impact on species diversity—From pattern to process. Oecologia, 132, 479-491. doi:10.1007/s00442-002-0988-3

Huebner, C. D., \& Vankat, J. L. (2003). The importance of environment vs. disturbance in the vegetation mosaic of Central Arizona. Journal of Vegetation Science, 14, 25-34. doi:10.1111/j.1654-1103.2003.tb02124.x

Imbeau, L., \& Desrochers, A. (2002). Foraging ecology and use of drumming trees by three-toed woodpeckers. Journal of Wildlife Management, 66, 222-231. doi: $10.2307 / 3802888$

Krasny, M. E., \& Whitmore, M. C. (1992). Gradual and sudden forest canopy gaps in Allegheny northern hardwood forests. Canadian Journal of Forest Research, 22, 139-143. doi:10.1139/x92-019

Krebs, C. J. (1989). Ecological methodology. New York, NY: Harper and Row Publishers Inc., $654 \mathrm{p}$.

Kuuluvainen, T., \& Juntunen, P. (1998). Seedling establishment in relation to microhabitat variation in a windthrow gap in a boreal Pinus sylvestris forest. Journal of Vegetation Science, 9, 551-562. doi: $10.2307 / 3237271$

Lenoir, J., Gégout, J.-C., Guisan, A., Vittoz, P., Wohlgemuth, T., Zimmermann, N. E., Dullinger, S., Pauli, H., Willner, W., Grytnes, J.-A., Virtanen, R., \& Svenning, J.-C. (2010) Crossscale analysis of the region effect on vascular plant species diversity in southern and northern European mountain ranges. PLOS ONE, 5, e15734. doi:10.1371/journal.pone.0015734

McGuire, A. D., Wirth, C., Apps, M., Beringer, J., Clein, J., Epstein, H., Kicklighter, D. W., Bhatti, J., Chapin III, F. S., de Groot, B., Efremov, D., Eugster, W., Fukuda, M., Gower, T., Hinzman, L., Huntley, B., Jia, G. J., Kasischke, E., Melillo, J., Romanovsky, V., Shvidenko, A., Vaganov, E., \& Walker, D. (2002). Environmental variation, vegetation distribution, carbon dynamics and water/energy exchange at high latitudes. Journal of Vegetation Science, 13, 301-314. doi:10.1111/j.1654-1103.2002.tb02055.x

Messaoud, Y., Bergeron, Y., \& Leduc, A. (2007). Ecological factors explaining the location of the boundary between the mixedwood and coniferous bioclimatic zones in the boreal biome of eastern North America. Global Ecology and Biogeography, 16, 90-102. doi:10.1111/j.1466-8238.2006.00277.x 
Morin, H. (1994). Dynamics of balsam fir forests in relation to spruce budworm outbreaks in the boreal zone of Quebec. Canadian Journal of Forest Research, 24, 730-741. doi:10.1139/x94-097

Morin, H., Laprise, D., Simard, A.-A., \& Amouch, S. (2008). Régime des épidémies de la Tordeuse des bourgeons de l'épinette dans l'Est de l'Amérique du Nord. In Aménagement écosystemique en forêt boréale (pp. 165-192). Quebec: University of Quebec Press.

MRNQ. (2003). Ministère des resources naturelles du Quebec. URL (last checked 24 July 2006). http://www.mrn.gouv.qc.ca

Nagel, T. A., \& Diaci, J. (2006). Intermediate wind disturbance in an old-growth beech-fir forest in southwestern Slovenia. Canadian Journal of Forest Research, 36, 629-638. doi:10.1139/x05-263

Neilson, R. P., King, G. A., De Velice, R. L., \& Lenihan, J. M. (1992). Regional and local vegetation patterns: The responses of vegetation diversity to subcontinental air masses. In Ecological Studies 92: Landscape boundaries: consequences for biotic diversity and ecological flows (pp. 129-149). New York: Springer-Verlag.

Novotny, V., \& Weiblen, D. B. (2005). From communities to continents: beta diversity of herbivorous insects. Annales Zoologici Fennici, 42, 463-475.

Osumi, K., Ikeda, S., \& Okamoto, T. (2003). Vegetation patterns and their dependency on site conditions in the pre-industrial landscape on north-eastern Japan. Ecological Research, 18, 753-765. doi:10.1111/j.1440-1703.2003.00593.x

Palmer, M., \& White, P. S. (1994). Scale dependence and the speciesarea relationship. American Naturalist, 144, 717-740. doi: $10.1086 / 285704$

Peterson, C. J. (2000). Catastrophic wind damage to North American forests and the potential impact of climate change. The Science of the Total Environment, 262, 287-311.

doi:10.1016/S0048-9697(00)00529-5

Pielou, E. C. (1966). The measurement of diversity in different types of biological collections. Journal of Theoretical Biology, 13, 131-144. doi:10.1016/0022-5193(66)90013-0

Qian, H., \& Ricklefs, R. E. (2007). A latitudinal gradient in large-scale beta diversity for vascular plants in North America. Ecology Letters, 10, 737-744. doi:10.1111/j.1461-0248.2007.01066.x

Reyes, G., \& Kneeshaw, D. (2008). Moderate-severity disturbance dynamics in Abies balsamea-Betula spp. forests: The relative importance of disturbance type and local stand and site characteristics on woody vegetation response. Ecoscience, 15, 241-249. doi:10.2980/15-2-3082

Reyes, G., Kneeshaw, D., De Grandpré, L., \& Leduc, A. (2010). Changes in woody vegetation abundance and diversity after natural disturbances causing different levels of mortality. Journal of Vegetation Science, 21, 406-417. doi:10.1111/j.1654-1103.2009.01152.x

Robitaille, A., \& Saucier, J. P. (1998). Paysages régionaux du Québec méridional. Québec: Les Publications du Québec.

Rodriguez-Garcia, E., Gratzer, G., \& Bravo, F. (2011). Climatic variability and other site factor influences on natural regeneration of Pinus pinaster Ait. in Mediterranean forests. Annals of Forest Science, 68, 811-823. doi:10.1007/s13595-011-0078-y

Shannon, C. E., \& Weaver, W. (1949). The mathematical theory of communication. Urbana, IL: University of Illinois Press.

SPSS Inc. (1999). Professional base system software for statistical analysis (v.10.0). Chicago, Illinois: SPSS Inc.

terBraak, C. J. F. \& Smilauer, P. (1998). CANOCO reference manual and user's guide to CANOCO for windows: Software for canonical community ordination (Version 4.02). New York: Microcomputer Power, Ithaca.

Turner, M. G., Dale, V. H., \& Everham III, E. H. (1997). Crown fires, hurricanes, and volcanoes: A comparison among large-scale disturbances. BioScience, 47, 758-768. doi:10.2307/1313098

van den Wollenberg, A. L. (1977). Redundancy analysis: An alternative for canonical correlation analysis. Psychometrika, 42, 207-219. doi:10.1007/BF02294050

Veblen, T. T., \& Ashton, D. H. (1978). Catastrophic influences on the vegetation of the Valdivian Andes, Chile. Vegetatio, 36, 149-167. doi:10.1007/BF02342598

Wang, X.-P., Tang, Z.-Y., \& Fang, J. Y. (2006). Climatic control on forests and tree species distribution in the forest region of northeast China. Journal of Integrative Plant Biology, 48, 778-789. doi:10.1111/j.1744-7909.2006.00294.x

Whittaker, R. H. (1960). Vegetation of the Siskiyou Mountains, Oregon and California. Ecological Monographs, 30, 279-338. doi: $10.2307 / 1943563$

Wimberly, M. C., \& Spies, T. A. (2001). Influences of environment and disturbance on forest patterns in coastal Oregon watersheds. Ecology, 82, 1443-1459. doi:10.1890/0012-9658(2001)082[1443:IOEADO]2.0.CO;2 